Dikirim: 16 Januari 2016 Diterbitkan: 1 Maret 2017

\section{Faktor risiko servisitis pada wanita pekerja seks di kegiatan layanan infeksi menular seksual mobile}

\section{Risk factors of cervicitis among female sex workers in sexual transmitted infection mobile service}

Mayta Sari Dwianggimawati ${ }^{1}$, Sunardi Radiono ${ }^{2}$, Theodola Baning Rahayujati $^{1}$

\begin{abstract}
Purpose: This study aimed to identify risk factors of cervicitis among female sex workers in the district of Cilacap. Methods: This study used a cross-sectional design. Total of respondents were 147 female sex workers who participated in the mobile sexual transmitted infection services. Demographic characteristic and risk factor data were collected by interviews using a structured questionnaire. Diagnosis of cervicitis was obtained by laboratory test with cervix swab. Data were analyzed using Poisson regression test with robust variance estimators. Results: Prevalence of cervicitis among female sex workers in the district of Cilacap were $70.75 \%$. Multivariate analysis showed that the risk factors of cervicitis among female sex worker were: age $\leq 24$ years old, income, childbirth history, number of clients per week, and inconsistent of condoms use. Conclusions: Results showed the need to increase awareness of condom use among female sex workers through health promotion and counseling in mobile sexual transmitted infection services by the teams of sexual transmitted infection clinics. Potential targets for outreach health promotions and counseling are younger female sex worker ( $\leq 30$ years old).
\end{abstract}

Keywords: cervicitis; female sex workers; risk factors

\footnotetext{
${ }^{1}$ Departemen Biostatistik, Epidemiologi dan Kesehatan Populasi, Fakultas Kedokteran, Universitas Gadjah Mada (Email: maytasari.d@mail.ugm.ac.id)

${ }^{2}$ Departemen Kulit dan Kelamin, Fakultas Kedokteran, Universitas Gadjah Mada
} 


\section{PENDAHULUAN}

Infeksi menular seksual berperan penting dalam epidemi HIV karena memicu penularan. Penelitian menunjukkan infeksi menular seksual menyebabkan penularan HIV menjadi lebih efisien karena adanya peningkatan sel limfosit di saluran genital menjadi target sel dari HIV. Penderita HIV+ dan mengalami infeksi menular seksual lebih mudah menularkan HIV pada pasangan seksual, karena konsentrasi HIV lebih tinggi pada cairan genital (1).

Servisitis termasuk infeksi menular seksual, tidak memiliki gejala dan jika tidak ditangani menyebabkan penyakit radang panggul, dapat membahayakan organ reproduksi dan infertilitas, kehamilan ektopik, dan radang panggul kronis (2). Patogen menyebabkan infeksi klamidia, infeksi gonore, infeksi non-gonokokal, dan servisitis mukopurulen.

Prostitusi merupakan salah satu masalah utama dalam penyebaran infeksi menular seksual. Wanita pekerja seks sebagai sasaran utama pada pengendalian infeksi menular seksual karena berisiko menularkan kepada klien dan memiliki mobilitas sangat tinggi. Terdapat 650.000 pekerja seks di Indonesia, 30\% diantaranya berusia di bawah 18 tahun, dan sebanyak 129.000 perempuan merupakan pekerja seks berusia di bawah umur 18 tahun (3).

Surveilans terpadu biologis dan perilaku di tahun 2011 menunjukkan wanita pekerja seks langsung mengalami sifilis $10 \%$ dan gonore $38 \%$, sementara pada wanita pekerja seks tidak langsung mengalami sifilis $3 \%$ dan gonore $56 \%$ (4). Penularan semakin meningkat seiring perkembangan pada bidang sosial demografis dan migrasi penduduk (5).

Wanita pekerja seksi di 9 provinsi di Indonesia mengalami infeksi menular seksual 64,0\%, klamidia $43,5 \%$, infeksi gonore 28,6\%, trikomoniasis $15,1 \%$. Infeksi klamidia tertinggi terdapat di Jawa Tengah. Penderita infeksi menular seksual berobat di rumah sakit kota Semarang tahun 2005-2010, angka kejadian servisitis berada di peringkat pertama (5.111 penderita) (6). Sedangkan, diagnosis infeksi menular seksual di kabupaten Kediri di tahun 2013 didominasi servisitis $42 \%$, kandidiasis $10,8 \%$, sifilis $(4,3 \%)$, dan trikomoniasis $3,4 \%$ (7).

Kabupaten Cilacap merupakan salah satu daerah berisiko terhadap kejadian infeksi menular seksual karena perkembangan pesat industri, pendidikan, dan tempat hiburan. Studi menunjukkan frekuensi hubungan seksual tinggi dan kesadaran pencegahan infeksi menular seksual rendah dalam pemakaian kondom pada klien, berkontribusi besar dalam penularan servisitis pada wanita pekerja seksual. Selama ini, prevalensi servisitis wanita di Indonesia belum pernah dilaporkan. Penelitian ini bertujuan untuk mengetahui faktor risiko servisitis pada wanita pekerja seksual.

\section{METODE}

Penelitian ini menggunakan rancangan cross sectional pada bulan Agustus-Oktober 2016. Sampel adalah 147 wanita pekerja seks langsung dan wanita pekerja seks tidak langsung, mengikuti kegiatan infeksi menular seksual mobile, berusia $\geq 18$ tahun, dan tidak haid/hamil. Pengumpulan data faktor risiko melalui wawancara dengan kuesioner terstruktur. Diagnosa servisitis ditentukan dokter berdasarkan pemeriksaan laboratorium sederhana (pengecatan gram atau metilen biru) dengan ditemukan minimal satu tanda meliputi terdapat cairan atau duh tubuh mukupurulen, lekosit polimorfonuklear $\geq 30$ per lapangan pandang, diplokokus intrasel $\geq 1$. Variabel penelitian adalah karakteristik demografi, riwayat reproduksi, perilaku berisiko, dan layanan infeksi menular seksual sebagai variabel bebas, dan diagnosa servisitis sebagai variabel terikat. Analisis data menggunakan Poisson regression with a robust variance estimator, dengan menyajikan prevalence ratio (PR), 95\% confidence interval (CI), dan level signifikansi $\mathrm{p}<0,05$.

\section{HASIL}

Pemeriksaan infeksi menular seksual menunjukkan prevalensi servisitis pada wanita pekerja seksual 70,75\%. Penelitian terhadap 63 wanita pekerja seks langsung di eks lokalisasi Slarang dan 84 wanita pekerja seks tidak langsung di tempat karaoke, Kabupaten Cilacap. Faktor risiko servisitis pada wanita pekerja seks seperti usia, pendapatan, riwayat melahirkan, rata-rata jumlah tamu per minggu, dan penggunaan kondom.

Wanita pekerja seks berusia $\leq 24$ tahun lebih berisiko 1,609 kali lebih besar mengalami servisitis daripada wanita pekerja seks berusia $\geq 25$ tahun. Wanita pekerja seks memiliki pendapatan sama atau di bawah upah minimun kerja lebih berisiko 1,283 kali lebih besar mengalami servisitis daripada wanita pekerja seks dengan pendapatan di atas upah minimun kerja. Wanita pekerja seks pernah melahirkan lebih berisiko 1,273 kali mengalami servisitis daripada wanita pekerja seks belum atau tidak pernah melahirkan. Selain itu, wanita pekerja seks dalam satu minggu memiliki rata-rata jumlah pelanggan $\geq 4$ lebih berisiko 
1,292 kali lebih besar untuk menderita servisitis daripada wanita pekerja seks dengan jumlah pelanggan $<4$ pelanggan per minggu. Wanita pekerja seksual yang tidak konsisten dalam menggunakan kondom berpeluang 1,44 kali lebih besar mengalami servisitis daripada wanita pekerja seks yang konsisten menggunakan kondom.

Tabel 1. Prevalens rasio servisitis wanita pekerja seks

\begin{tabular}{|c|c|c|c|}
\hline Variabel & Servisitis & $\begin{array}{c}\text { Tidak } \\
\text { Servisitis }\end{array}$ & PR (95\% CI) \\
\hline \multicolumn{4}{|l|}{ Usia } \\
\hline$\leq 24$ tahun & 61 & 16 & $1,289^{*}$ \\
\hline$>24$ tahun & 43 & 27 & $(1,036-1,605)$ \\
\hline \multicolumn{4}{|l|}{$\begin{array}{l}\text { Status } \\
\text { pernikahan }\end{array}$} \\
\hline Tidak menikah & 86 & 30 & 1,277 \\
\hline Menikah & 18 & 13 & $(0,928-1,757)$ \\
\hline \multicolumn{4}{|c|}{ Jenis wanita pekerja seks } \\
\hline Langung & 48 & 15 & 1,143 \\
\hline Tidak langsung & 56 & 28 & $(0,931-1,404)$ \\
\hline \multicolumn{4}{|l|}{ Pendidikan } \\
\hline Rendah & 64 & 17 & $1,304^{*}$ \\
\hline Tinggi & 40 & 26 & $(1,041-1,633)$ \\
\hline \multicolumn{4}{|l|}{ Pendapatan } \\
\hline$\leq \mathrm{UMK}$ & 29 & 6 & $1,237^{*}$ \\
\hline > UMK & 75 & 37 & $(1,013-1,511)$ \\
\hline \multicolumn{4}{|c|}{ Lama menjadi wanita pekerja seks } \\
\hline$\leq 2$ tahun & 61 & 22 & 1,094 \\
\hline$>2$ tahun & 43 & 21 & $(0,882-1,357)$ \\
\hline \multicolumn{4}{|c|}{ Tarif transaksi seksual } \\
\hline Rendah & 14 & 6 & 0,988 \\
\hline Tinggi & 90 & 37 & $(0,725-1,345)$ \\
\hline \multicolumn{4}{|c|}{ Usia HUS pertama } \\
\hline$\leq 16$ tahun & 35 & 7 & $1,268^{*}$ \\
\hline$>16$ tahun & 69 & 36 & $(1,044-1,539)$ \\
\hline \multicolumn{4}{|c|}{ Riwayat melahirkan } \\
\hline Pernah & 76 & 25 & 1,236 \\
\hline Tidak & 28 & 18 & $(0,945-1,600)$ \\
\hline \multicolumn{4}{|l|}{ Riwayat aborsi } \\
\hline Pernah aborsi & 12 & 3 & 1,148 \\
\hline Tidak pernah & 92 & 40 & $(0,869-1,515)$ \\
\hline \multicolumn{4}{|c|}{ Kontrasepsi hormonal } \\
\hline $\mathrm{Ya}$ & 43 & 17 & 1,022 \\
\hline Tidak & 61 & 26 & $(0,839-1,262)$ \\
\hline \multicolumn{4}{|c|}{ Jumlah pelanggan } \\
\hline$\geq 4$ per minggu & 58 & 12 & 1,387 \\
\hline$<4$ per minggu & 46 & 31 & $(1,121-1,716)$ \\
\hline \multicolumn{4}{|c|}{ Penggunaan kondom } \\
\hline Inkonsisten & 77 & 19 & $1,515^{*}$ \\
\hline Konsisten & 27 & 24 & $(1,147-2,001)$ \\
\hline \multicolumn{4}{|c|}{ Douching vagina } \\
\hline $\mathrm{Ya}$ & 87 & 35 & 1,049 \\
\hline Tidak & 17 & 8 & $(0,783-1,405)$ \\
\hline \multicolumn{4}{|c|}{ Kecukupan kondom } \\
\hline Tidak cukup & 29 & 14 & 0,935 \\
\hline Cukup & 75 & 29 & $(0,735-1,189)$ \\
\hline \multicolumn{4}{|c|}{ Distribusi kondom } \\
\hline Klinik & 11 & & $1,331^{*}$ \\
\hline Outlet kondom & & & $(1,083-1,634)$ \\
\hline Membeli & 93 & 42 & \\
\hline \multicolumn{4}{|l|}{ Jarak layanan } \\
\hline Sulit dijangkau & 3 & & 0,812 \\
\hline $\begin{array}{l}\text { Mudah } \\
\text { dijangkau }\end{array}$ & 85 & 30 & $(0,392-1,679)$ \\
\hline \multicolumn{4}{|c|}{ Pemberi layanan } \\
\hline Perawat/bidan & 20 & 6 & 1,026 \\
\hline $\begin{array}{l}\text { Perawat/bidan } \\
\text { dan dokter }\end{array}$ & 57 & 19 & $(0,799-1,315)$ \\
\hline
\end{tabular}

Tabel 2. Faktor yang memengaruhi servisitis wanita pekerja seks

\begin{tabular}{llc}
\hline \multicolumn{1}{c}{ Variabel } & aPR & 95\% CI \\
\hline Usia $\leq 24$ tahun & 1,609 & $1,304-1,987^{*}$ \\
Pendapatan $\leq$ UMK & 1,283 & $1,055-1,560^{*}$ \\
Riwayat melahirkan & 1,273 & $1,006-1,610^{*}$ \\
$\begin{array}{l}\text { Rata-rata } \geq 4 \text { pelanggan } \\
\text { per minggu }\end{array}$ & 1,292 & $1,039-1,606^{*}$ \\
$\begin{array}{l}\text { Penggunaan kondom } \\
\text { tidak konsisten }\end{array}$ & 1,440 & $1,082-1,917^{*}$ \\
\hline
\end{tabular}

\section{BAHASAN}

Servisitis merupakan kondisi umum pada wanita pekerja seks dengan prevalensi $>20 \%$. Penelitian dari Gaydos menjelaskan prevalensi servisitis pada wanita yang berobat ke klinik infeksi menular seksual di kota Baltimore sebesar 41,05\% (7). Infeksi klamidia dan gonore adalah dua agent terbesar penyebab servisitis. Penelitian Dewayani menjelaskan bahwa 62,7\% wanita pekerja seks mengalami servisitis mukopurulenta (8). Sebanyak 62,50\% wanita pekerja seks positif menderita servisitis klamidia. Studi pada wanita pekerja seks di 9 provinsi Indonesia menunjukkan prevalensi infeksi menular seksual 64\%, infeksi klamidia 43,5\%, infeksi gonore $28,6 \%$, dan trikomoniasis $15,1 \%$.

Wanita pekerja seks berusia lebih muda berisiko lebih tinggi mengalami servisitis daripada wanita pekerja seks berusia lebih tua. Wanita berusia lebih muda secara biologis lebih rentan terhadap infeksi di mukosa serviks karena adanya ektopi serviks. Ektopi serviks merupakan kondisi dimana epitel serviks pada wanita usia muda berlapis silinder, rentan terhadap infeksi menular seksual. Servisitis klamidia sering ditemukan pada wanita kelompok usia muda, karena secara fisiologis mukosa serviks ektopi lebih banyak dijumpai pada remaja. Pada wanita aktif seksual, frekuensi servisitis klamidia tertinggi dijumpai pada usia 15-21 tahun dan menurun seiring pertambahan usia. Kelompok usia lebih muda mempunyai aktivitas seksual lebih tinggi daripada kelompok lain, sehingga risiko penularan trikomoniasis dari pasangannya lebih besar. Usia 18-30 tahun merupakan faktor risiko infeksi klamidia pada wanita pekerja seks.

Wanita pekerja seks dengan pendapatan rendah berrisiko lebih tinggi mengalami servistis daripada wanita pekerja seks dengan penghasilan tinggi. Pendapatan digunakan untuk memenuhi kebutuhan hidup. Gaya hidup wanita pekerja seks boros dan konsumtif. Wanita pekerja seks dengan tingkat pembayaran rendah atau menengah memiliki risiko tertular infeksi menular seksual lebih tinggi karena 
memiliki pelanggan dengan sosial ekonomi dan tingkat pendidikan rendah.

Tingkat pendapatan memengaruhi seseorang untuk menggunakan layanan kesehatan dan penyediaan kondom. Pendapatan yang memadai memberikan kesempatan lebih besar bagi wanita pekerja seks untuk datang ke layanan kesehatan, memeriksakan diri, dan membayar pengobatan. Pendapatan merupakan faktor motivasi dalam berperilaku, penyediaan dan penggunaan kondom. Prevalensi gonore lebih sedikit pada wanita pekerja seks dengan imbalan jasa lebih besar daripada tarif rata-rata setiap kali berhubungan seksual.

Wanita pekerja seks memiliki riwayat melahirkan risiko lebih tinggi mengalami servistis daripada wanita pekerja seks belum atau tidak pernah melahirkan. Periode sesaat setelah melahirkan merupakan waktu rentan bagi wanita terhadap infeksi menular seksual atau HIV, meskipun belum jelas apakah disebabkan oleh peningkatan kerentanan pada vagina dan serviks setelah melahirkan, atau karena mitra seksual telah berhubungan seksual dengan wanita lain selama kehamilan. Paritas sangat berkaitan dengan jarak kelahiran. Semakin tinggi paritas, maka semakin pendek jarak kelahiran. Pada multipara dengan ostium uteri eksternum sudah lebih terbuka, batas ke atas dari daerah bebas kuman ialah ostium uteri internum sehingga lebih rentan terjadi infeksi oleh berbagai kuman masuk dari luar atau oleh kuman endogen.

Wanita pekerja seks memiliki jumlah pelanggan per minggu $\geq 4$ memiliki risiko lebih tinggi terkena servistis daripada wanita pekerja seks dengan pelanggan per minggu <4. Peningkatan jumlah pelanggan membuat frekuensi hubungan seksual semakin sering sehingga meningkatkan paparan pada wanita pekerja seks. Frekuensi hubungan seksual termasuk faktor penting, memperbesar penularan infeksi menular seksual karena perubahan frekuensi dan pasangan seksual (10). Peningkatan frekuensi dan variasi pasangan seks menyebabkan jumlah pelanggan berhubungan dengan kejadian servisitis. Wanita pekerja seks dengan jumlah pelanggan lebih dari mengalami infeksi gonore dan klamidia. Peningkatan jumlah mitra seksual baru pada wanita merupakan faktor risiko tertular servisitis. Wanita pekerja seks di 9 provinsi Indonesia dengan rata-rata jumlah pelanggan $\geq 4$ pelanggan setiap minggu berisiko 1,5 kali lebih besar mengalami infeksi gonore dan klamidia daripada wanita pekerja seks dengan jumlah pelanggan $<4$.

Wanita pekerja seks tidak konsisten menggunakan kondom saat berhubungan seksual dengan pelanggan sehingga berisiko lebih tinggi mengalami servistis daripada wanita pekerja seks menggunakan kondom. Saat ini penggunaan kondom untuk mencegah penularan infeksi menular seksual dan HIV. Penggunaan kondom tidak konsisten meningkatkan risiko infeksi klamidia dua kali lebih besar. Penurunan risiko penularan gonore pada lelaki karena menggunakan kondom 49-75\% daripada lelaki tidak menggunakan kondom saat berhubungan seksual dan ditemukan $0 \%$ infeksi klamidia pada lelaki jika menggunakan kondom daripada lelaki jarang atau tidak pernah menggunakan kondom.

\section{SIMPULAN}

Faktor risiko servisitis pada wanita pekerja seks adalah usia, pendapatan, riwayat melahirkan, rata-rata jumlah tamu per minggu, dan penggunaan kondom. Perlu upaya peningkatan kesadaran penggunaan kondom bagi wanita pekerja seks melalui kegiatan penyuluhan dan konseling di setiap kegiatan layanan infeksi menular seksual mobile dari tim klinik infeksi menular seksual. Kegiatan penyuluhan dan konseling lebih diutamakan pada wanita pekerja seks berusia muda ( $\leq 30$ tahun) sebagai sasaran potensial.

\section{Abstrak}

Tujuan: Penelitian ini bertujuan untuk mengetahui faktor risiko servisitis pada wanita pekerja seksual. Metode: Penelitian menggunakan rancangan cross sectional analitik. Responden adalah 147 wanita pekerja seksual dalam layanan infeksi menular seksual mobile di klinik infeksi menular seksual Times dan klinik infeksi menular seksual Citra. Data faktor risiko dari wawancara dengan kuesioner terstruktur. Data dianalisis menggunakan Poisson regression with robust variance estimator. Hasil: Prevalensi servisitis pada wanita pekerja seks di kabupaten Cilacap sebesar 70,75\%. Faktor risiko servisitis meliputi usia, pendapatan, riwayat melahirkan, rata-rata jumlah tamu per minggu, dan penggunaan kondom. Siimpulan: Perlu upaya peningkatan kesadaran penggunaan kondom bagi wanita pekerja seks melalui kegiatan penyuluhan dan konseling di setiap kegiatan layanan infeksi menular seksual mobile oleh tim dari klinik infeksi menular seksual.

Kata kunci: servisitis; wanita pekerja seks; faktor risiko 


\section{PUSTAKA}

1. Dallabetta G, Laga M, Lamptey P. Control of sexually transmitted diseases: a handbook for the design and management of programs.

2. American College of Physicians. In The Clinic: Vaginitis and Cervicitis. 2009.

3. Herowati. Pengetahuan dan Perilaku Pekerja Seks Komersial terhadap Infeksi Menular Seksual di Parangkusumo Kretek Bantul. Tesis Fakultas Kedokteran Universitas Gadjah Mada. 2004.

4. Kementerian Kesehatan. STBP 2011 Surveilans Terpadu Biologis dan Perilaku. 2012.

5. Kementerian Kesehatan. Pedoman Nasional Penanganan Infeksi Menular Seksual. Jakarta. 2011.

6. Iskandar FN, Puspitaningrum D, Mulyanti L. Hubungan antara sikap wanita usia subur (usia 20-35 tahun) terhadap perilaku pencegahan servisitis dengan pemeriksaan skrining di kelurahan kalibanteng kulon lebdosari semarang tahun 2013. Jurnal Kebidanan. 2013;2(2):66-71.

7. Kharisun. Faktor-Faktor Berhubungan dengan Kejadian Infeksi Menular Seksual Berulang pada Wanita Penjaja Seks Langsung di kabupaten Kediri Provinsi Jawa Timur. Tesis Fakultas Kedokteran Universitas Gadjah Mada. 2014.

8. Gaydos C, Maldeis NE, Hardick A, Hardick J, Quinn TC. Mycoplasma genitalium as a contributor to the multiple etiologies of cervicitis in women attending sexually transmitted disease clinics. Sexually transmitted diseases. 2009 Oct;36(10):598.

9. Dewayani M, Wirohadidjoyo YW. Dipstik leukosit esterase untuk diagnosis servisitis mukopurulenta Kajian pada wanita pekerja seks. Berkala Ilmu Kedokteran. 1996;28(1996).

10. Garnett GP. The transmission dynamics of sexually transmitted infections. Sexually transmitted diseases, 4th edn. New York: McGraw-Hill. 2008:27-39. 
Berita Kedokteran Masyarakat, Volume 33 No. 3 Tahun 2017 